\title{
IMPACT OF THE HYDRAULIC LOADING RATE ON THE HYDRODYNAMIC CHARACTERISTICS OF AN ANAEROBIC FIXED BED REACTOR TREATING CATTLE SLAUGHTERHOUSE WASTEWATER
}

\author{
Cristiane Kreutz $^{*}$, Karina Q. de Carvalho², Fernando H. Passig', Aldria D. Belini², \\ Cláudia S. de C. M. dos S. Cordovil ${ }^{3}$, Simone D. Gomes ${ }^{4}$
}

1*Corresponding author. Universidade Tecnológica Federal do Paraná/ Campo Mourão - PR, Brasil. E-mail: ckreutz@utfpr.edu.br

\section{KEYWORDS}

dead space volume, hydraulic efficiency, hydraulic short, circuiting, residence, time distribution.

\begin{abstract}
The hydrodynamic behavior of an anaerobic fixed bed reactor (AFBR) was evaluated in the treatment of cattle slaughterhouse wastewater. The AFBR was operated at hydraulic retention time (HRT) of 14,11 and $8 \mathrm{~h}$. Stimulus-response assays were carried out with Eosin $\mathrm{Y}$ and the experimental data were adjusted to the single-parameter theoretical models of dispersion and $\mathrm{N}$-continuous stirred tank reactors in series (N-CSTR). The experimental results of the residence time distribution curves showed that at lower flow rate, the reactor showed plug flow behavior with correlation coefficient (r) of 0.88 and number of dispersion of 0.2 for high dispersion (HD). However, at higher and intermediate flow rates, the AFBR behave as a complete mixture flow, (r) of 0.94 and 0.96, respectively. Residence time distribution curves in the AFBR showed a good approximation of the complete mixing model at hydraulic residence time of 11 and $8 \mathrm{~h}$, with 5 and $2 \mathrm{~N}$-CSTR reactors in series, respectively. The volume of dead zones corresponding to 43.0, 37.4 and $11.2 \%$ of the volume of the reactor for HRT of 14, 11 and $8 \mathrm{~h}$, respectively, was noted, and hydraulic short circuiting were not confirmed.
\end{abstract}

\section{INTRODUCTION}

Most of the meat slaughterhouse wastewater is composed of high organic matter concentrations, nutrients such as nitrogen and phosphorus and pathogens and nonpathogenic microorganisms (Debik \& Coskun, 2009; Cao \& Mehrvar, 2011; De Nardi et al., 2011). Thus, biological processes are used in the treatment of this slaughterhouse wastewater type primarily to remove organic pollution. When considering the characteristics of wastewater generated in the meat processing industry, Alexandre et al. (2011), Kayranli \& Ugurlu (2011) and Tansengco et al. (2015) concluded that the anaerobic biological processes show many advantages, such as efficiency at reducing Chemical Oxygen Demand (COD) in both soluble and insoluble forms, and the methane production that can be recovered and used as an energy source.

Anaerobic fixed bed reactors (AFBRs) are based on the use of support medium for the immobilization of microorganisms, which has led to its recent widespread use in different types of waste treatment, especially because this immobilization reduces the hydraulic retention time (HRT).

Kerčmar \& Pintar (2017) claimed that the material had an influence on the microbial metabolic activity as well as on the quantity and quality characteristics of the immobilized microbial community, when testing anaerobic up-flow bioreactors to investigate the crucial bacteria sensitive period in the immobilization process. The results obtained suggest that the material support dictates the outcome of the immobilization process in the anaerobic continuous-flow bioreactor.

Due to the diffusive character of the flow passing through these fixed-bed reactors, there is a lack of studies that describe the hydrodynamic behavior of these complex treatment systems. For this reason, the knowledge of the hydrodynamic behavior, the flow characteristics, retention time and the reactor geometry are critical to the optimization of the process because they enable problem detection and resolution, thus improving their overall efficiency.

\footnotetext{
${ }^{2}$ Universidade Tecnológica Federal do Paraná/ Curitiba - PR, Brasil.

${ }^{3}$ Universidade de Lisboa, Instituto Superior de Agronomia/ Lisboa, Portugal.

${ }^{4}$ Universidade Estadual do Oeste do Paraná/ Cascavel - PR, Brasil. 
Levenspiel (2000) and Fogler (2006) acknowledged two ideal mixing reactor models, being the first one the Continuous Stirred-Tank Reactor in series (CSTR), in which the liquid remains homogeneous because of constant mixing in the tank, e.g., axial dispersion; and the second model is a plug-flow reactor in which the flow passes through the tank, perfectly mixed in the radial direction, with no axial dispersion. A reactor is considered non-ideal when the Residence Time Distribution (RTD) cannot be described by either of these models.

Residence Time Distribution curves can help in the establishment of flow regimes (plug flow, complete mixture flow or both), determination of the hydrodynamic parameters (real $\theta$, number of reactors in series, dispersion number, tracer recovery and hydraulic efficiency) and identification of flow anomalies inside the reactor (dead zones, preferential paths and/or hydraulic short circuits). These anomalies may reduce the efficiency of the reactors treating wastewater due to the decrease of useful volume and hydraulic retention time required to the performance of the microbial activity as noted by Abbas et al. (2015).

According to Mansouri et al. (2012), the hydrodynamic behavior in any biological reactor is of fundamental importance for the efficiency of wastewater treatment processes. The hydrodynamics and degree of mixing that occur within a biological reactor strongly influence the extent of contact between the substrate and bacteria, thus controlling mass transfer.

Therefore, this study sought to evaluate the hydrodynamic behavior of a bench scale anaerobic fixed bed reactor treating cattle slaughterhouse wastewater. In the first part of this research, the hydrodynamics was studied experimentally by interpreting the Residence Time Distribution curves. Then, in the second part of this research, starting from the hydrodynamic results, the anomalies dead zones and hydraulic short circuiting were evaluated and hydraulic efficiency was calculated.

\section{MATERIAL AND METHODS}

\section{Experimental apparatus and operational conditions}

The anaerobic fixed bed reactor (AFBR) is constituted of one plexiglass tube of internal diameter of $90 \mathrm{~mm}$, length of $1000 \mathrm{~mm}$ and useful volume of $4.75 \mathrm{~L}$, formed by a feeding chamber and a reaction bed. The reactor was operated with continuous upflow regime and kept at room temperature. The AFBR feeding was performed by a dosing pump PROVITEC ${ }^{\circledR}$ model DM 5000 .

The material used for biomass fixation consists of expanded clay with an average particle size ranging from 5 to $15 \mathrm{~mm}$ and cubic matrices of polyurethane foam $(1 \mathrm{~cm}$ sides, $23 \mathrm{~kg} \mathrm{~m}^{-3}$ density and $95 \%$ porosity). Clay was chosen as the first support medium because it facilitates the adherence of acidogenic organisms and prevents the medium clogging. The polyurethane foam modulus was inoculated with anaerobic sludge from a pond treating cattle abattoir wastewater.

The reactor was operated for 108 days and continuously fed with raw wastewater collected in the entrance of the settling tank of the treatment system of a cattle slaughterhouse. The wastewater characteristics used in the AFBR feeding are shown in Table 1, corresponding to 18 samples. All the parameters were determined according to the methodologies described in APHA (2012), in duplicate.

TABLE 1. Composition of raw cattle slaughterhouse wastewater used as substrate to AFBR reactor feeding.

\begin{tabular}{|c|c|c|c|c|}
\hline \multirow{2}{*}{ Parameters } & \multicolumn{4}{|c|}{ Values } \\
\hline & $\overline{\mathbf{X}}$ & SD & MIN & MAX \\
\hline $\mathrm{pH}$ & 6.9 & 0.6 & 6.1 & 8.1 \\
\hline Temperature $\left({ }^{\circ} \mathrm{C}\right)$ & 25.2 & 1.9 & 20.1 & 27.8 \\
\hline $\mathrm{BA}\left(\mathrm{mgCaCO}_{3} \mathrm{~L}^{-1}\right)$ & 536 & 379 & 117 & 1,340 \\
\hline VA $\left(\mathrm{mgHAc} \mathrm{L}^{-1}\right)$ & 344 & 179 & 50 & 782 \\
\hline COD raw $\left(\mathrm{mg} \mathrm{L}^{-1}\right)$ & 965 & 107 & 821 & 1,274 \\
\hline COD filtered $\left(\mathrm{mg} \mathrm{L}^{-1}\right)$ & 877 & 111 & 586 & 1,006 \\
\hline $\mathrm{TS}\left(\mathrm{mg} \mathrm{L}^{-1}\right)$ & 2,840 & 1,797 & 1,638 & 9,558 \\
\hline TSS $\left(\mathrm{mg} \mathrm{L}^{-1}\right)$ & 573 & 611 & 35 & 2,440 \\
\hline
\end{tabular}

Legend: $\overline{\mathbf{x}}$ : average; SD: standard deviation; MIN: minimum value: MAX: maximum value; temperature of the liquid;

COD: chemical oxygen demand in raw and filtered samples; TS - total solids; TSS - total suspended solids.

The reactor was inoculated with approximately $2 \mathrm{~L}$ of anaerobic sludge obtained from a cattle slaughterhouse pond. The TS and volatile suspended solids VSS concentrations of the biomass used as inoculum in the AFBR were 1,514 and 347 $\mathrm{mg} \mathrm{L}^{-1}$, respectively.

\section{Determination of hydrodynamic characteristics}

The hydrodynamic behavior of the AFBR was evaluated at hydraulic retention time (HRT) of 14,11 and $8 \mathrm{~h}$, corresponding to the influent flowrate of $0.34 \mathrm{~L} \mathrm{~h}^{-1}, 0.43 \mathrm{~L} \mathrm{~h}^{-1}$ and $0.6 \mathrm{~L} \mathrm{~h}^{-1}$ and volumetric organic load (VOL) of $8.0 \mathrm{~g} \mathrm{~L}-1 \mathrm{~d}^{-1}$, $10.2 \mathrm{~g} \mathrm{~L}^{-1} \mathrm{~d}^{-1}$ and $13.3 \mathrm{~g} \mathrm{~L}^{-1} \mathrm{~d}^{-1}$, respectively. These operational conditions are presented in Table 2.

To evaluate the hydrodynamic behavior, three stimulus-response assays were carried out using Eosin $\mathrm{Y}\left(691.9 \mathrm{~g} \mathrm{~g}^{-1} \mathrm{~mol}^{-1}\right)$ dye as a tracer. 
TABLE 2. Operational conditions of the hydrodynamic assays realized in this study

\begin{tabular}{ccccccc}
\hline Phase & $\begin{array}{c}\text { Operation } \\
\text { (days) }\end{array}$ & Useful volume $(\mathbf{L})$ & $\begin{array}{c}\text { HRT } \\
\text { (h) }\end{array}$ & $\begin{array}{c}\text { Influent Flowrate } \\
\left(\mathbf{L h}^{-\mathbf{1}}\right)\end{array}$ & $\begin{array}{c}\text { VOL applied } \\
\left(\mathbf{g L}^{\mathbf{- 1}} \mathbf{d}^{\mathbf{- 1}}\right)\end{array}$ & $\begin{array}{c}\text { Tracer } \\
\text { concentration } \\
\left(\mathbf{m g m L}^{-\mathbf{1}}\right)\end{array}$ \\
\hline I & $1-36$ & 4.75 & 14 & 0.34 & 8.0 & 20 \\
\hline II & $37-72$ & 4.75 & 11 & 0.43 & 10.2 & 20 \\
\hline III & $73-108$ & 4.75 & 8 & 0.60 & 13.3 & 20 \\
\hline
\end{tabular}

Stimulus-response technique is commonly used to study the liquid mixing of non-ideal flow. A pulse injection of tracer was performed in the input stream of the AFBR at time $\mathrm{t}=0$, and the tracer concentration $\mathrm{C}(\mathrm{t})$ was measured at the outlet. The injection volume and injection tracer time were $10 \mathrm{~mL}$ and $10 \mathrm{~s}$, respectively, for each assay.

The total duration of the assay was of three times the theoretical hydraulic retention time $\left(\theta_{t}\right)$ for each assay, with collection of effluent samples at regular intervals of
45 minutes. The samples were centrifuged for $2 \mathrm{~min}$ at $3,500 \mathrm{rpm}$ in a centrifuge $\mathrm{Sislab}^{\circledR}$ model Twister $12 \mathrm{~T}$ to avoid the interference of solids in the absorbance reading. The tracer concentration in the effluent samples was determined using the colorimetric method of reading absorbance at $516 \mathrm{~nm}$ using a UV-VIS spectrophotometer (Hach, model DR/5000).

Data analyses determined the values of the terms defined in Table 3.

TABLE 3. Definition of the variables used to obtain the RTD function (E $\theta$ ) as a function of the dimensionless mean residence time $(\theta)$.

\begin{tabular}{|c|c|}
\hline Variable & Definition \\
\hline $\mathrm{E}_{\mathrm{i}}$ & $\frac{C_{i}}{S}$ \\
\hline \multicolumn{2}{|l|}{$\mathrm{S}$} \\
\hline $\mathrm{t}_{\mathrm{r}}$ & $\frac{\sum t_{i} \cdot C_{i} \cdot \Delta t_{i}}{\sum C_{i} \cdot \Delta t_{i}}$ \\
\hline$\theta$ & $\frac{t}{t_{R}}$ \\
\hline $\mathrm{E}_{\theta}$ & $t_{R} \cdot E_{i}$ \\
\hline$\sigma^{2}$ & $\frac{\sum t_{i}^{2} \cdot C_{i} \cdot \Delta t_{i}}{\sum C_{i} \cdot \Delta t_{i}}-t_{R}^{2}$ \\
\hline$\sigma_{\theta}^{2} \theta$ & $\frac{\sigma^{2}}{t_{R}^{2}}$ \\
\hline
\end{tabular}

Legend: $\mathrm{E}_{\mathrm{i}}=$ exit age distribution curve $[\mathrm{T}]^{-1} ; \mathrm{C}_{\mathrm{i}}=\operatorname{tracer}$ concentration $[\mathrm{M}][\mathrm{L}]^{-3} ; \mathrm{S}=$ area under the concentration-time curve $[\mathrm{M}][\mathrm{T}][\mathrm{L}]^{-3} ; \mathrm{t}_{\mathrm{r}}$ $=$ mean residence time obtained $[\mathrm{T}] ; \mathrm{t}_{\mathrm{i}}=$ time interval; $\theta=$ dimensionless mean residence time; $\mathrm{t}=$ time $[\mathrm{T}] ; \mathrm{E}_{\theta}=$ distribution of hydraulic residence time function; $\sigma^{2}=$ variance $[\mathrm{T}]^{2} ; \sigma^{2}{ }_{\theta}=$ dimensionless variance.

According to Levenspiel (2000), the variation experimental curves of the tracer concentration against time $(\mathrm{C}(\mathrm{t}))$ yield the distribution hydraulic residence time curves $\left(E_{\theta}\right)$ as a function of dimensionless time $(\theta)$. The dimensionless variance $\left(\sigma^{2}{ }_{\theta}\right)$ of each assay was calculated after the normalization (area under the curve equal to 1).

The experimental curves adjustment was based on the dispersion of low intensity (LD), high intensity (HD) and continuous-stirred reactors in series (N-CSTR). The dispersion models simulated the actual reactor using a tubular flow reactor in which axial dispersion occurs through a series of $\mathrm{N}$ ideal stirred tanks. These parameters were estimated from the variance of the response data presented in Table 4. 
TABLE 4. Single-parameter hydrodynamic theoretical models.

\begin{tabular}{ccc}
\hline Models & Parameter & Equation \\
\hline Low Dispersion & $\sigma_{\theta}^{2}=2\left(\frac{D}{u \cdot L}\right)$ & $E_{\theta}=\frac{1}{2 \sqrt{\pi(D / u . L)}} \exp \left[-\frac{(1-\theta)^{2}}{4(D / u . L)}\right]$ \\
\hline High Dispersion & $\sigma^{2}{ }_{\theta, t a}=2\left(\frac{D}{u \cdot L}\right)+8\left(\frac{D}{u \cdot L}\right)^{2}$ & $E_{\theta, t a}=\frac{1}{2 \sqrt{\pi(D / u . L)}} \exp \left[-\frac{(1-\theta)^{2}}{4 \theta(D / u . L)}\right]$ \\
\hline N-CSTR in series & $N=\frac{1}{\sigma_{\theta}^{2}}=\frac{\bar{\theta}^{2}}{\sigma^{2}} \quad E_{\theta}=\frac{N(N \cdot \theta)^{N-1}}{(N-1) !} e^{-N \cdot \theta}$
\end{tabular}

Where, $\theta=$ dimensionless mean residence time; $\sigma^{2} \theta_{\theta}=$ dimensionless variance; $\mathrm{D}=$ dispersion coefficient $[\mathrm{L}]^{2}[\mathrm{~T}]^{-1} ; \mathrm{E}_{\theta}=\mathrm{distribution}$ of hydraulic residence time function; $\mathrm{E}_{\mathrm{i}}=$ exit age distribution curve $[\mathrm{T}]^{-1} ; \mathrm{t}_{\mathrm{r}}=$ mean residence time obtained $[\mathrm{T}] ; \mathrm{N}=$ number of reactors in series; $\mathrm{D} / \mu \mathrm{L}=$ reactor dispersion number; $\mathrm{C}_{\mathrm{i}}=$ tracer concentration $[\mathrm{M}][\mathrm{L}]^{-3} ; \sigma^{2}=$ variance $[\mathrm{T}]^{2} ; \mathrm{S}=$ area under the concentration-time curve $[\mathrm{M}][\mathrm{T}][\mathrm{L}]^{-3} ; \mathrm{t}=$ time; $\mathrm{t}_{\mathrm{i}}=$ time interval.

\section{Determination of anomalies}

Volume of dead zones was calculated according to the methodology reported by Montiel et al. (2016), as expressed in eqs (1) and (2).

$$
\begin{aligned}
& \beta=\frac{t_{0}}{t} \\
& \mathrm{I}_{\mathrm{d}}=\frac{\mathrm{V}_{\mathrm{d}}}{\mathrm{V}}=1-\beta
\end{aligned}
$$

Where,

$$
\begin{aligned}
& \beta=\text { hydraulic efficiency (dimensionless); } \\
& \mathrm{t}_{\mathrm{o}}=\text { theoretical hydraulic retention time }(\mathrm{h}) ; \\
& \mathrm{t}=\text { mean residence time from tracer experiment }(\mathrm{h}) ; \\
& \mathrm{I}_{\mathrm{d}}=\text { dead volume fraction (dimensionless); } \\
& \mathrm{V}_{\mathrm{d}}=\text { dead volume }(\mathrm{L}), \text { and } \\
& V=\text { reactor volume }(\mathrm{L}) .
\end{aligned}
$$

The presence of hydraulic short circuiting $(\Psi)$ was verified by the ratio between the time of the first tracer appearance in the effluent (peak $-\tau_{\mathrm{k}}$ ) and the theoretical hydraulic retention time $\left(\theta_{t}\right)$ in the effluent of the reactor in accordance with the methodology adapted by Sarathai et al. (2010) as described in [eq. (3)].

$$
\Psi=\frac{\tau \mathrm{k}}{\mathrm{HRTe}}
$$

The theoretical hydraulic retention time $\left(\theta_{\mathrm{t}}\right)$ was calculated as $\mathrm{V} / \mathrm{Q}$, where, $\mathrm{V}$ is the useful volume of the reactor $(\mathrm{L})$ and $\mathrm{Q}$ is the influent flowrate $\left(\mathrm{L} \mathrm{h}^{-1}\right)$.

\section{RESULTS AND DISCUSSION}

The concentration curves for the response type assays in an AFBR reactor operated with 14, 11 and $8 \mathrm{~h}$ of the mean residence time are shown in Figure 1.
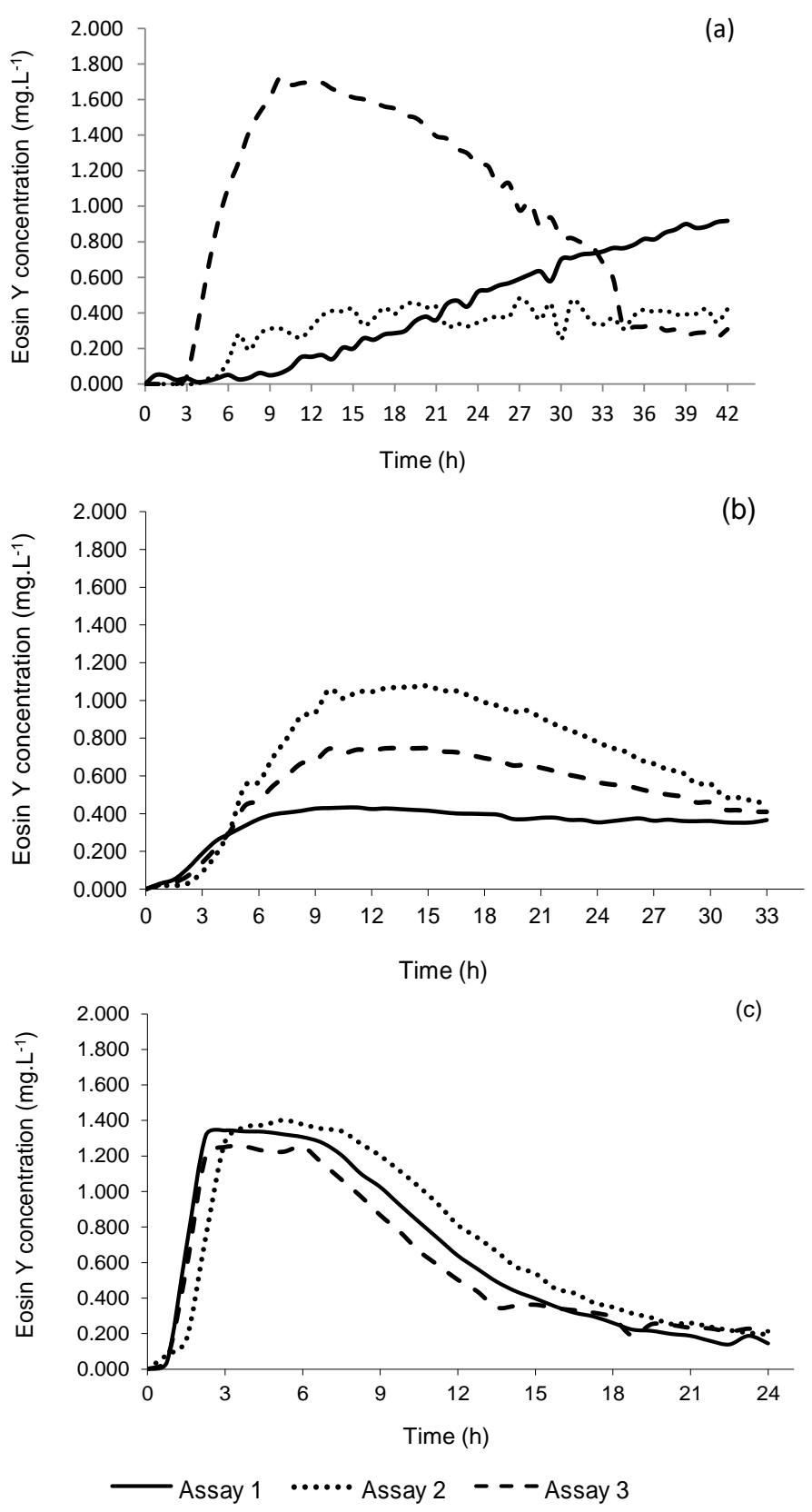

FIGURE 1. Variation of the Eosin Y concentration over time in samples of effluent from AFBR at (a) $14 \mathrm{~h}$, (b) $11 \mathrm{~h}$, and (c) $8 \mathrm{~h}$. 
Although the assays were conducted with a total duration of three times the theoretical hydraulic retention $\theta t$ time for each assay, i.e., with approximately $42 \mathrm{~h}, 33 \mathrm{~h}$ and $24 \mathrm{~h}$, the concentrations of the tracer equal to zero were not detected in the last readings.

Long tail phenomena can be noted on experimental curves obtained for all the assays, more accentuated for HRT of $8 \mathrm{~h}$ (Figure 1c), reflecting the slow decay of the tracer concentrations at the outlet. This tail may also represent the tracer diffusion in dead zones inside the reactor or retention due to interactions between the Eosin $\mathrm{Y}$ and biomass and/or support material of the AFBR.

According to Souza et al. (2011) the tail phenomenon is explained by the fact that before the introduction of the tracer into the reactor, the support material pores are filled with water, so the concentration of the tracer in the pores is equal to zero. As the tracer in the form of pulse passes through the bed, the concentration of tracer in the flow increases and a gradient is formed. Currently, the diffusion occurs from the main flow toward the packing material pores. Then, when the pulse passes, the concentration of tracer in the main flow tends to decrease and eventually becomes lower than the concentration within the pores. It causes inversion of the gradient and diffusion begins to occur in the opposite direction.

Fia et al. (2016) and Zeng et al. (2013) attributed this phenomenon to the tracer diffusion between the biofilm and substrate, considerable diffusion of the tracer into the biofilm, presence of dead zones or stagnation of the reactor, or eventually hydraulic short circuiting.

Pérez-Pérez et al. (2017) concluded that the presence of zeolite, used as material support in an expanded granular sludge bed (EGSB) reactor, caused higher values of dead zones, ranging from $12.3 \%$ to $24.2 \%$ and stated that the higher the zeolite bed the higher the percentage of dead zones in the EGSB reactor. Therefore, it can be observed that the characteristics of support medium influence the hydrodynamic behavior of reactors, as evidenced by the increase of HRTr due to the increase of zeolite bed height and upflow velocity.

The initial peak with an exponential decrease is typical of packed-bed reactors (Figure 1c), indicating a non-ideal behavior with the presence of dispersion, bypassing and stagnant zone in the bed. Moreover, Figure 1a shows the occurrence of small intermediate peaks, which may represent the existence of internal recirculation on AFBR reactor according to Levenspiel (2000).

The experimental RTD curves with different HRTs and the adjusted single-parameter mathematical models for continuous-stirred reactors in series (N-CSTR), low dispersion (LD) and high dispersion (HD) are represented in Figure 2. The experimental data shown in Figure 2 refer to the average of the three profiles performed for each HRT.
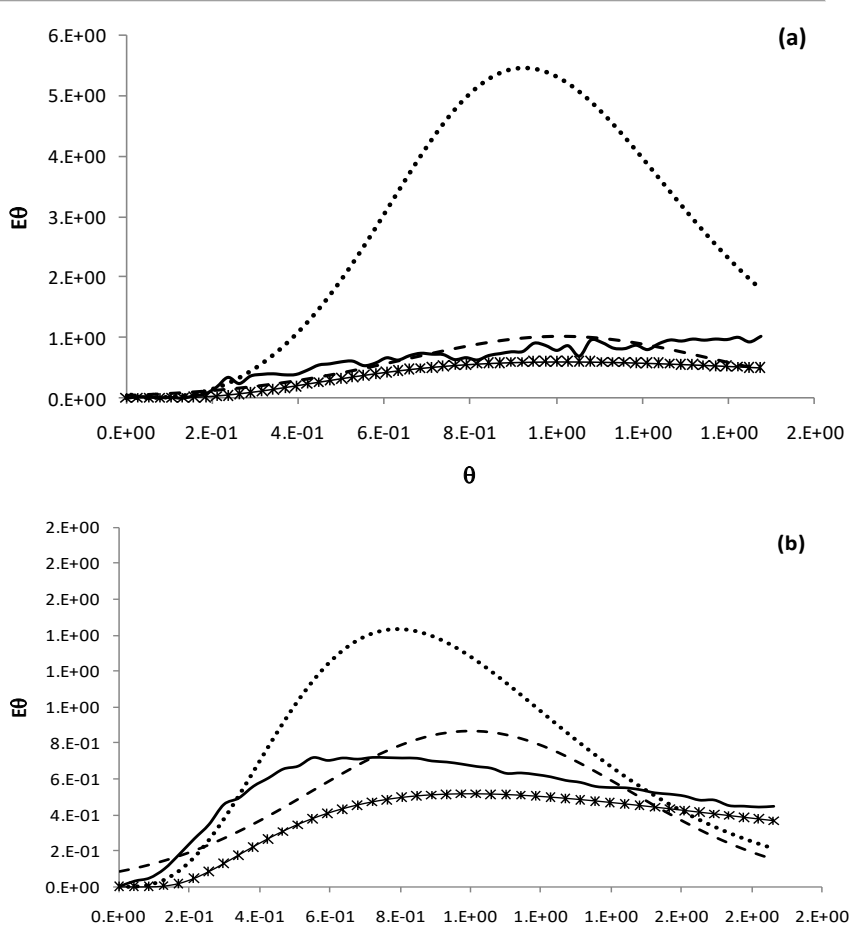

$\theta$

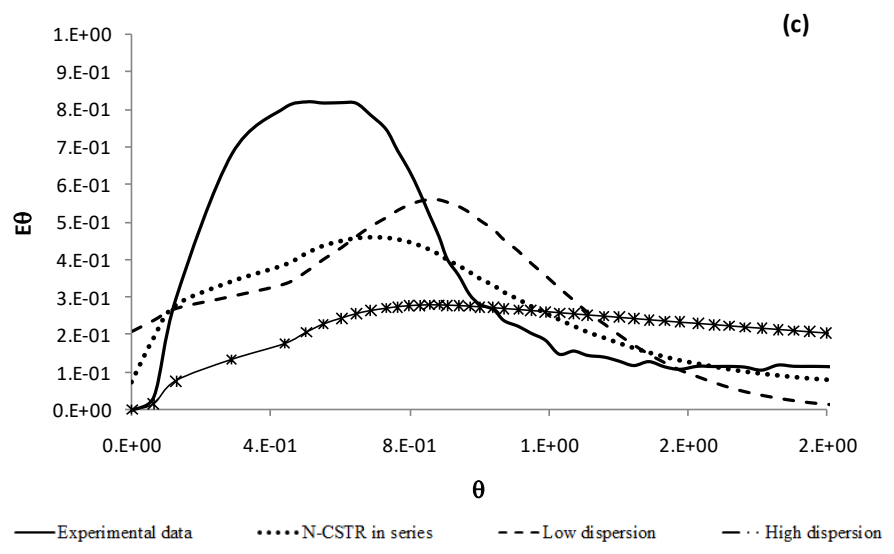

FIGURE 2. Results of RTD curves obtained experimentally for HRT at (a) $14 \mathrm{~h}$, (b) $11 \mathrm{~h}$, and (c) $8 \mathrm{~h}$.

In Figure 2, the peaks for the experimental data indicate preferred pathways in the AFBR. Greater oscillations in the tracer response occurred at an HRT of $14 \mathrm{~h}$, which may be resulted from the internal recirculation of this tracer in the reactor. Fia et al. (2016) also observed a delay in the response of the tracer, which may be linked to adsorption of the tracer by the biomass, or the existence of internal recirculation zones or dead zones inside the UASB reactors and ASBF, characterized by isolated or inaccessible regions where the imprisoned fluid does not interact with active regions.

The results of the hydrodynamic parameters, obtained experimentally from the residence distribution time (RTD) curves, after the adjustment by the singleparameter theoretical models, are shown in Table 5.

The adjustment of the experimental data by the theoretical model of N-CSTR in series resulted in approximately 6,5 and 2 reactors in series for HRT of 14, 11 and $8 \mathrm{~h}$, respectively (Table 5), indicating its decrease with the increase of the influent flowrate from 0.34 to 0.43 and to $0.60 \mathrm{~L} \mathrm{~h}^{-1}$. 
TABLE 5. Results of the parameters and correlation coefficients obtained after adjusting the experimental data using mathematical models for each assay in AFBR reactor

\begin{tabular}{cccccccc}
\hline \multirow{2}{*}{ HRT $_{\mathbf{t}}(\mathbf{h})$} & \multirow{2}{*}{ HRT $_{\mathbf{e}}(\mathbf{h})$} & \multirow{2}{*}{ N-CSTR } & \multicolumn{3}{c}{ D/ $\boldsymbol{\mu L}$} & \multicolumn{3}{c}{ Correlation coefficient (r) } \\
\cline { 3 - 8 } & & & $(\mathbf{L D})$ & $\mathbf{H D})$ & N-CSTR & LD & HD \\
\hline 14 & 24.6 & 6 & 0.08 & 0.2 & 0.70 & 0.70 & 0.88 \\
\hline 11 & 17.7 & 5 & 0.09 & 0.3 & 0.94 & 0.88 & 0.85 \\
\hline 8 & 9.0 & 2 & 0.20 & 0.8 & 0.96 & 0.72 & 0.33 \\
\hline
\end{tabular}

HRT $_{t}$ - Theoretical hydraulic retention time (h); HRT - Experimental hydraulic retention time (h); N-CSTR - Number of continuous-stirred reactors in series (N-CSTR); D/ $\mu \mathrm{L}$ - dispersion number; $\mathrm{LD}$ - low dispersion; HD - high dispersion.

The same behavior was noted to the dispersion models with $\mathrm{D} / \mu \mathrm{L}$ of $0.08,0.09$ and 0.20 for $\mathrm{LD}$ model and $\mathrm{D} / \mu \mathrm{L}$ of $0.2,0.3$ and 0.8 for HD model to HRT of 14 , 11 and $8 \mathrm{~h}$, respectively.

Levenspiel (2000) concludes that dispersion numbers vary for different degrees of dispersion. A large dispersion number $(\mathrm{D} / \mu \mathrm{L} \rightarrow \infty)$ indicates a perfectly mixed system, whereas a small dispersion number $(D / \mu \mathrm{L}$ $\rightarrow 0$ ) indicates an ideal plug flow system. Summarizing $\mathrm{D} / \mu \mathrm{L}$ values between $0.000-0.002,0.002-0.025$ and 0.025-0.200 indicate a small, intermediate and large amount of dispersion, respectively.

In the assays carried out with Eosin Y, it may be considered that the correlation between the experimental data and the HD model was better compared with the other models analyzed, for the HRT at $14 \mathrm{~h}$, with a correlation coefficient of 0.88 . Based on the results and the tracer response curves for the HRT of 11 and $8 \mathrm{~h}$, the behavior of AFBR reactor reflects more closely a completely mixed flow system, with a correlation coefficient of 0.94 and 0.96, respectively. Rincón et al. (2011) studied the hydraulic behavior of a double-chamber anaerobic reactor. The evaluation was performed at the liquid phase and in operation, using $\mathrm{Li}^{+}(\mathrm{LiCl})$ as a tracer. The reactor was described as a plug flow, with $\mathrm{D} / \mu \mathrm{L}=0.25$ in both chambers and a hydraulic efficiency close to the unit (1), indicating an almost null presence of dead zones.

The values of dispersion number, which were observed in the range $0.09-0.3$ for HRT of $11 \mathrm{~h}$ and 0.20 -0.8 to $8 \mathrm{~h}$, indicate an intermediate amount of dispersion in the reactor. The values of dispersion number increased with the decrease of the reactor HRT, thereby signifying that the dispersion increases with reduction in hydraulic residence time.

The experimental tracer results allow stating that according to increase in organic load applied noted an increase the number of dispersion in the AFBR. So, it may be noted that higher loading rates yielded actual retention times closer to the theoretical retention time, consequently, higher loading rates increased dispersion and plug flow ratios. The flow regime may be considered as an intermediate model of plug flow approaching of the completely mixed flow when decreased the HRT. This occurrence is associated with the likely combination of tracer mechanical dispersion factor or molecular diffusion.

The hydraulic characteristics of the flow in the reactor are shown in Table 6.

TABLE 6. Hydraulic characteristics estimated of the AFBR reactor.

\begin{tabular}{cccccccc}
\hline & \multicolumn{7}{c}{ Hydraulic characteristics } \\
\hline Phase & $\mathrm{t}_{\mathrm{o}}(\mathrm{h})$ & $\mathrm{t}(\mathrm{h})$ & $\beta$ & $\mathrm{V}_{\mathrm{d}}(\mathrm{L})$ & $\mathrm{I}_{\mathrm{d}}$ & $\mathrm{V}_{\mathrm{d}}(\%)$ & \\
\hline I & 14 & 24.6 & 0.569 & 2.04 & 0.430 & 43.0 & 0.793 \\
II & 11 & 17.7 & 0.621 & 1.78 & 0.374 & 37.4 & 0.763 \\
III & 8 & 9 & 0.889 & 0.53 & 0.112 & 11.2 & 0.416 \\
\hline
\end{tabular}

Legend: $t_{0}=$ theoretical hydraulic retention time; $t=$ mean residence time from tracer experiment;

$\beta=$ hydraulic efficiency (dimensionless), $V_{d}=$ dead volume; $I_{d}=$ dead volume fraction (dimensionless); $\Psi=$ hydraulic short circuiting.

Analyzing the results presented in Table 6, a delay of approximately $75.7 \%, 60.9 \%$ and $12.5 \%$ in the response of Eosin Y was observed to the theoretical HRT of 14, 11 and $8 \mathrm{~h}$, respectively, thus the curves with the extended tail effect reflect the slow decay of the concentration detected at the outlet point of the reactor as also observed by Lourenço \& Campos (2009).

Zago et al. (2017) noted a delay for the hydrodynamic behavior of anaerobic-aerobic fixed-bed reactors using Eosin y as a tracer. The experimental HRTs, reported by these researchers, showed a mean delay of $33.3 \%$ and $39.4 \%$ for $\mathrm{R} 1$ and $\mathrm{R} 2$, respectively, most likely caused by the long tail effect observed in the experimental curves.

The long tail effect suggests the presence of dead zones or tracer diffusion into the reactor; thus, the larger the dead zone volume, the greater the tail area. Wang et al. (2015) studied an electrochemical membrane bioreactor (EMBR) that has recently been developed for energy recovery and wastewater treatment. These authors observed that a long tail appeared in each RTD curve, especially at HRT values of 3.12 and $7.02 \mathrm{~h}$, indicating a presence of stagnant or dead zones in the EMBR and the release of the tracer slow with flow stream in these regions. Méndez-Romero et al. (2011) reported that biomass can occupy a significant volume of the reactor and can be considered as part of the dead zone volume. Stevens et al. (1986) suggested that the tracer diffusion in the reactor seems to be a reasonable explanation for most of the discrepancies between the theoretical and experimental residence times observed in studies of hydrodynamic behavior. 
Matangue et al. (2016) carried out the evaluation of the hydrodynamic behavior of anaerobic baffled reactor (ABR), set in pilot scale and continuously fed with liquid effluent from swine manure, using lithium chlorine as tracer under steady-state operational condition using stimulus response techniques. The theoretical hydraulic retention time (HRT) adopted was $16 \mathrm{~h}$. The average residence time $(\mathrm{t})$ found was $24.5 \mathrm{~h}$ with the number of dispersion (d) of 0.13 and the flow pattern characterized as plug-flow with great axial dispersion. The percentage of dead zones was about $26 \%$ and volumetric efficiency ranged from 35 to $100 \%$.

The hydraulic short circuiting values were 0.414 , 0.763 and 0.793 for HRT at 8,11 and $14 \mathrm{~h}$, respectively. These results indicated that effects were not significant in the AFBR reactor. According to Angeloudis et al. (2015), hydraulic short circuiting occurs when particles pass through a reactor faster than the theoretical hydraulic residence time; and to Rengers et al. (2016) short circuiting can occur when the inlet jet into the reactor with high velocity, and part of the flow is diverted toward the system outlet, so that volume of liquid exits the system in a much lower time than the theoretical residence time.

\section{CONCLUSIONS}

In this experiment was observed the presence of tail effect that is primarily attributed to the diffusion of the tracer in the polyurethane foam pores or to the dead zones regions formed inside the reactor because of the expanded clay, used as support medium. Experimental hydraulic retention time showed an average delay of approximately $75.7 \%, 60.9 \%$ and $12.5 \%$ compares to the theoretical HRT of 14,11 and $8 \mathrm{~h}$, respectively.

When operated with HRT at $14 \mathrm{~h}$, the AFB reactor may be considered as a high dispersion model with correlation coefficient of 0.88 , but with HRT at 11 and $8 \mathrm{~h}$ the results of the tracer response curves indicated that their behavior reflects more closely a completely mixed system with correlation coefficients of 0.94 and 0.96 , respectively. The hydrodynamics assessment of the AFBR reactor demonstrated that the tanks in series model presented $\mathrm{N}$ equal to 6,5 and 2 to HRT of 14,11 and $8 \mathrm{~h}$, respectively.

Regarding to the anomalies, the presence of dead zones was reported, occupying $43 \%, 37.4 \%$ and $11.2 \%$ of the volume of the AFBR reactor when operated with HRT of $14 \mathrm{~h}, 11 \mathrm{~h}$ and $8 \mathrm{~h}$, respectively. Hydraulic short circuiting was not detected.

\section{ACKNOWLEDGEMENTS}

This research was supported by the Conselho Nacional de Desenvolvimento Científico e Tecnológico CNPq under Grant 482321/2009-1; and Coordenação de Aperfeiçoamento de Pessoal de Nível Superior - Capes under Grant 1511114.

\section{REFERENCES}

Abbas G, Wanga L, Zhanga H, Zheng P, Li W, Zhang M, Zeb BS, Zhang J (2015) Evaluation of hydraulic characteristics of a pilot-scale air-lift internal-loop bioreactor. Journal of Environmental Science and Health, Part A: Toxic/Hazardous Substances and Environmental Engineering 50:332-339.
Alexandre VMF, Valente AM, Cammarota MC, Freire DMG (2011) Performance of anaerobic bioreactor treating fish-processing plant wastewater pre-hydrolyzed with a solid enzyme pool. Renewable Energy 36:3439-3444.

Angeloudis A, Stoesser T, Falconer RA, Kim D (2015) Flow, transport and disinfection performance in small- and full-scale contact tanks. Journal of Hydro-environment Research 9:15-27.

APHA, AWWA (2012) Standard Methods for the Examination of Water and Wastewater. Washington, DC, American Public Health Association, $22^{\text {st }}$ ed.

Cao W, Mehrvar M (2011) Slaughterhouse wastewater treatment by combined anaerobic baffled reactor and $\mathrm{UV} / \mathrm{H} 2 \mathrm{O} 2$ processes. Chemical Engineering Research and Design 89:1136-1143.

De Nardi IR, Del Nery V, Amorim AKB, Santos NG dos, Chimenes F (2011) Performances of SBR, chemical-DAF and UV disinfection for poultry slaughterhouse wastewater reclamation. Desalination. 269:184-189.

Debik E, Coskun T (2009) Use of the Static Granular Bed Reactor (SGBR) with anaerobic sludge to treat poultry slaughterhouse wastewater and kinetic modeling. Bioresource Technology 100:2777-2782.

Fia FRL, Fia R, Campos CMM, Oliveira LFC de (2016) Hydrodynamic behavior of a combined anaerobic-aerobic system employed in the treatment of vinasse. Ciência e Agrotecnologia 40(6): 718-729.

Fogler HS (2006) Elements of chemical reaction engineering. New Jersey, Pearson Education.

Kayranli B, Ugurlu A (2011) Effects of temperature and biomass concentration on the performance of anaerobic sequencing batch reactor treating low strength wastewater. Desalination 278:77-83.

Kerčmar J, Pintar A (2017) Support material dictates the attached biomass characteristics during the immobilization process in anaerobic continuous-flow packed-bed bioreactor, Anaerobe. DOI:

http://dx.doi.org/10.1016/j.anaerobe.2017.06.007

Levenspiel O (2000) Engenharia das reações químicas. São Paulo, Ed. Edgard Blücher, 3ed.

Lourenço AMP, Campos CMM (2009) Hydrodynamic behavior of a lab-scale upflow anaerobic sludge blanket reactor (UASB) operated with an adopted hydraulic retention time (HRT) of 12 hours. Ciência e Agrotecnologia (33):1139-1144.

Mansouri Y, Zinatizadeh AA, Mohammadi P, Irandoust M, Akhbari A, Davoodi R (2012) Hydraulic characteristics analysis of an anaerobic rotatory biological contracto (AnRBC) using tracer experiments and response surface methodology (RSM). Korean Journal of Chemical Engineering 28(7):891-902. 
Matangue MTA, Campos CMM, Pereira E, Amorim F, Vila Boas R (2016) Hydrodynamic behaviour of a pilot scale anaerobic baffled reactor treating SWINE wastewater from farming. Journal of Soil Science and Environmental Management 7(1):1-9.

Méndez-Romero DC, López A, Vallejo-Rodríguez R, León-Becerril E (2011) Hydrodynamic and kinetic assessment of an anaerobic fixed-bed reactor for slaughterhouse wastewater treatment. Chemical Engineering and Processing: Process Intensification 50:273-280.

Montiel JIP, Villasmil A, Gerardo J, Rojano REA (2016) Evaluación hidráulica de un reactor anaerobio de flujo ascendente (RAFA) usando un modelo de dispersión axial. Revista Internacional de Contaminación Ambiental 32(3):281-291.

Pérez-Pérez T, Correia GT, Kwong WH, Pereda-Reyes I, Oliva-Merencio D, Zaiat M (2017) Effects of the support material addition on the hydrodynamic behavior of an anaerobic expanded granular sludge bed reactor. Journal of Environmental Sciences 54:224-230.

Rengers EE, Silva JB, Paulo PL, Janzen JG (2016) Hydraulic performance of a modified constructed wetland system through a CFD-based approach. Journal of Hydroenvironment Research 12:91-104.

Rincón N, Galindo A, Pérez J (2011) Evaluación del comportamiento hidráulico en un reactor anaerobio de doble cámara (RADCA). Rev. Fac. Ing. Univ. Antioquia 61:53-63.

Sarathai Y, Koottatep T, Morel A (2010) Hydraulic characteristics of an anaerobic baffled reactor as onsite wastewater treatment system. Journal of Environmental Sciences 22:1319-1326.
Souza THY, Pantoja-Filho JLR, Zaiat M, Foresti E (2011) Hydrodynamic characterization of an alternative twochambers reactor applied in the tertiary treatment of sewage. In: 10th Latin American Workshop and Symposium on Anaerobic Digestion (DAAL). Ouro Preto, IWA, Proceedings...p1-9.

Stevens DK, Berthouex PM, Chapman TW (1986) The effect of tracer diffusion in biofilm on residence time distributions. Water Research 20:369-375.

Tansengco M, Herrera D, Tejano J, Yao M, Beraye JR, Esguerra R (2015) Biological Treatment of Meat Processing Wastewater using Anaerobic Sequencing Batch Reactor (ASBR). International Research Journal of Biological Sciences 4(3):66-75.

Wang Y-Z, He C-S, Yang H-Y, Sheng G-P, Shen J-Y, Mu Y, Yu H-Q (2015) Hydrodynamics of an Electrochemical Membrane Bioreactor Scientific Reports 5:10387.

Zago AF, Arantes EJ, Passig FH, Carvalho KQ, Crispim JQ, Kreutz C (2017) Análise Dos Desvios De Idealidade Em Reatores Combinados Anaeróbio-Aeróbios De Leito Fixo. In: III Congresso Ibero-Americano de Empreendedorismo, Energia, Ambiente e Tecnologia, 2017, Bragança, Portugal. p33-37.

Zeng M, Soric A, Ferrasse JH, Roche N (2013) Interpreting hydrodynamic behaviour by the model of stirred tanks in series with exchanged zones: preliminary study in lab-scale trickling filters. Environmental Technology 34:2571-2578. 